\title{
Article \\ Deviation of Trypsin Activity Using Peptide Conformational Imprints
}

\author{
Kiran Reddy Kanubaddi ${ }^{1,+}{ }^{\dagger}$ Pei-Yu Huang ${ }^{2,+}$, Ya-Lin Chang ${ }^{2}$, Cheng Hsin $\mathrm{Wu}^{2}$, Wei $\mathrm{Li}^{2}$, \\ Ranjith Kumar Kankala ${ }^{1,3}$ (D), Dar-Fu Tai ${ }^{2, *}$ and Chia-Hung Lee ${ }^{1, *}$ \\ 1 Department of Life Science, National Dong Hwa University, Hualien 97401, Taiwan; \\ 810513107@gms.ndhu.edu.tw (K.R.K.); ranjithkankala@hqu.edu.cn (R.K.K.) \\ 2 Department of Chemistry, National Dong Hwa University, Hualien 97401, Taiwan; \\ 610012029@gms.ndhu.edu.tw (P.-Y.H.); m9812003@ems.ndhu.edu.tw (Y.-L.C.); \\ m9812022@gms.ndhu.edu.tw (C.H.W.); ga025361@yahoo.com.tw (W.L.) \\ 3 College of Chemical Engineering, Huaqiao University, Xiamen 361021, China \\ * Correspondence: dftai@gms.ndhu.edu.tw (D.-F.T.); chlee016@gms.ndhu.edu.tw (C.-H.L.) \\ + These authors contributed equally to this work.
}

check for

updates

Citation: Kanubaddi, K.R.; Huang, P.-Y.; Chang, Y.-L.; Wu, C.H.; Li, W.; Kankala, R.K.; Tai, D.-F.; Lee, C.-H. Deviation of Trypsin Activity Using Peptide Conformational Imprints. Nanomaterials 2021, 11, 334. https:// doi.org/10.3390/nano11020334

Academic Editor: Paolo Arosio

Received: 3 December 2020

Accepted: 22 January 2021

Published: 27 January 2021

Publisher's Note: MDPI stays neutral with regard to jurisdictional claims in published maps and institutional affiliations.

Copyright: (c) 2021 by the authors. Licensee MDPI, Basel, Switzerland. This article is an open access article distributed under the terms and conditions of the Creative Commons Attribution (CC BY) license (https:/ / creativecommons.org/licenses/by/ $4.0 /)$.

\begin{abstract}
In this study, a methodology utilizing peptide conformational imprints (PCIs) as a tool to specifically immobilize porcine pancreatic alpha-trypsin (PPT) at a targeted position is demonstrated. Owing to the fabrication of segment-mediated PCIs on the magnetic particles (PCIMPs), elegant cavities complementary to the PPT structure are constructed. Based on the sequence on targeted PPT, the individual region of the enzyme is trapped with different template-derived PCIMPs to show certain types of inhibition. Upon hydrolysis, $N$-benzoyl-L-arginine ethyl ester (BAEE) is employed to assess the hydrolytic activity of PCIMPs bound to the trypsin using high-performance liquid chromatography (HPLC) analysis. Further, the kinetic data of four different PCIMPs are compared. As a result, the PCIMPs presented non-competitive inhibition toward trypsin, according to the Lineweaver-Burk plot. Further, the kinetic analysis confirmed that the best parameters of $\mathrm{PPT} / \mathrm{PCIMPs}{ }^{233-245+\mathrm{G}}$ were $V_{\max }=1.47 \times 10^{-3} \mathrm{mM} \mathrm{s}^{-1}, K_{m}=0.42 \mathrm{mM}, k_{\text {cat }}=1.16 \mathrm{~s}^{-1}$, and $k_{\text {cat }} / K_{m}=2.79 \mathrm{mM}^{-1} \mathrm{~s}^{-1}$. As PPT is bound tightly to the correct position, its catalytic activities could be sustained. Additionally, our findings stated that the immobilized PPT could maintain stable activity even after four successive cycles.
\end{abstract}

Keywords: porcine pancreatic trypsin; molecularly-imprinted polymers; magnetic particles; conformational imprint; secondary structure

\section{Introduction}

Porcine pancreatic alpha-trypsin (PPT), a proteolytic enzyme, is a pancreatic serine protease (EC 3.4.21.4) with specificity for arginine or lysine substrate towards catalytic hydrolysis on esters and amides, under mild reaction conditions [1-3]. Owing to these facts, this proteolytic enzyme is often utilized in industrial and biomedical applications $[1,4,5]$. However, such enzymes are often immobilized into various substrates to improve stability and reusability without affecting their activity [2,6,7]. In this vein, various enzyme immobilization methods have been reported, such as covalent linkage, non-covalent adsorption, and encapsulation systems, among others [8-12]. Nevertheless, the quest for optimum performance is still on due to their conformational changes during immobilization $[11,13]$. Although an enzyme possesses a uniform structure, it often changes the conformation continuously. Consequently, the immobilized biocatalyst is organized randomly during/after immobilization, resulting in different constitutions and a less dynamic form.

In recent times, the utilization of molecularly imprinted polymers (MIPs) has become an emerging carrier-bound system for the immobilization of biomolecules, as they offer reversible orientation [14]. In this context, the incorporation of MIPs with magnetic particles 
(MPs) was first demonstrated by Ansell and Mosbach [15]. Since then, several efforts have been dedicated to the utilization of MIPs for diverse applications. In a case, Tong and colleagues applied MPs to recognize Ribonuclease A [16]. In another case, Jing and coworkers used lysozyme as a template to adsorb blood specimens with a detection limit at $5 \mathrm{ng} / \mathrm{mL}$ [17]. Previously, trypsin was utilized as the template to generate MIPs for different assays and inhibition studies [18]. Nonetheless, the employment of such a template for MPs was restricted to the usage of the whole protein.

Considering these facts, herein, we demonstrate an elegant method to immobilize PPT. As segment-mediated MIPs were fabricated on MPs, cavities complementary to PPT structure were constructed on those nanomaterials. As the imprinting of a random coil peptide successfully generates the desired nano-cavity for the corresponding peptide/protein $[19,20]$, recently, a helical peptide was utilized as a template to generate helical cavities with high affinity for the target protein, having achieved satisfactory results [21]. Accordingly, in this work, several PPT peptide segments were selected to generate helix cavities, using peptide conformational imprints decorated over the magnetic particles (PCIMPs). This study is divided into four main steps: (i) Fabricating peptide conformational imprint (PCIs) on MPs carriers; (ii) adsorbing trypsin to PCIMPs; (iii) analyzing the binding kinetics of immobilized PPT; and (iv) evaluating the reusability of immobilized PPT. The immobilization of PPT based on the PCIs was carried out as illustrated in Figure 1.

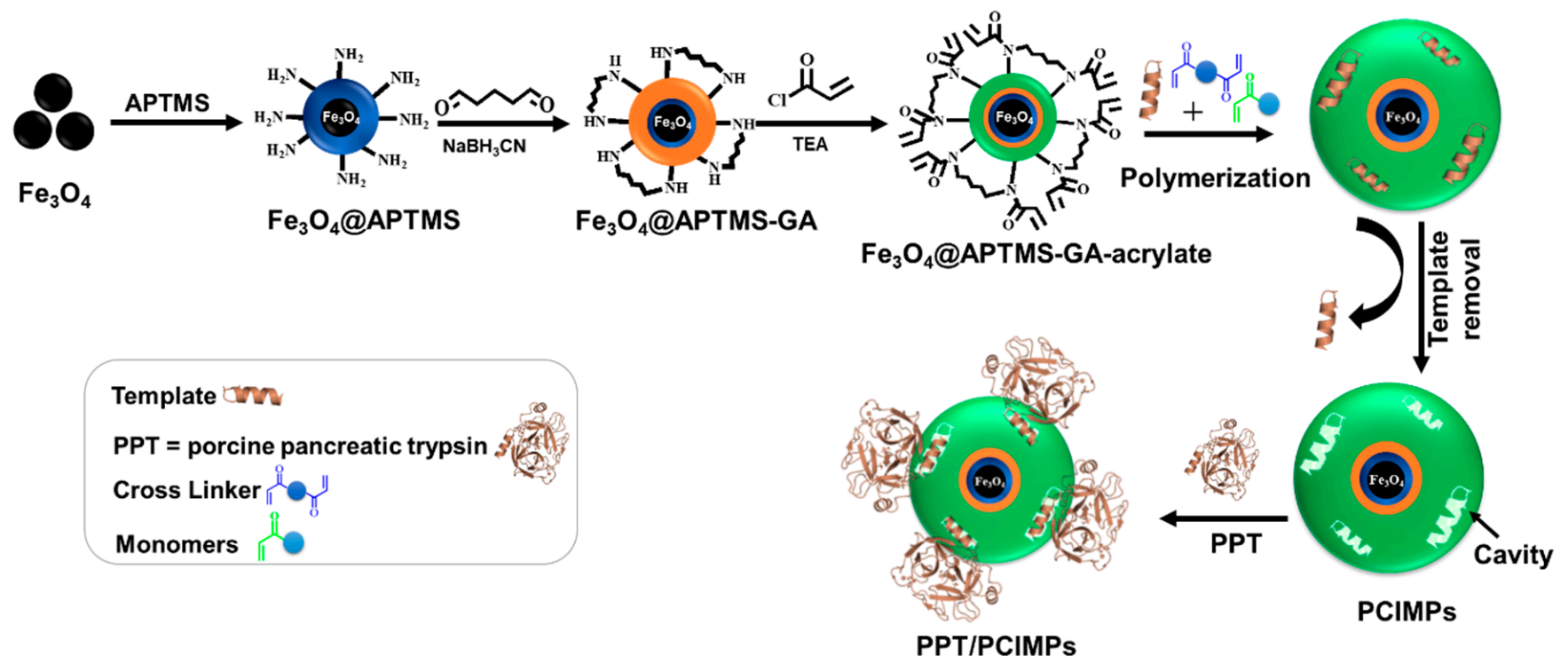

Figure 1. Scheme illustrating the fabrication of peptide conformational imprints (PCIs) on magnetic particles (MPs) and their binding to porcine pancreatic alpha-trypsin (PPT).

\section{Materials and Methods}

\subsection{Reagents and Chemicals}

3-(Aminopropyl) trimethoxysilane (APTMS) and ammonium acetate $\left(\mathrm{NH}_{4} \mathrm{Ac}\right)$ were obtained from Acros Ltd. (Fair Lawn, New Jersey, United States). Iron (III) chloride hexahydrate $\left(\mathrm{FeCl}_{3} \cdot 6 \mathrm{H}_{2} \mathrm{O}\right)$ and triethylamine (TEA) were purchased from Merck Ltd. (Darmstadt, Germany). $N, N^{\prime}$-Ethylene bisacrylamide (EBAA) and $N$-benzyl acrylamide (BAA) were acquired from Lancaster (Lancashire, UK). Glutaraldehyde (GA) was obtained from Ferax (Berlin, Germany). All Fmoc-amino acids were purchased from BAChem (Bubendorf, Switzerland). Acrylamide (AM), acetic acid, N-benzoyl-L-arginine ethyl ester (BAEE), sodium cyanoborohydride $\left(\mathrm{NaBH}_{3} \mathrm{CN}\right), N, N, N^{\prime}, N^{\prime}$-tetramethyl ethylene diamine (TEMED), tris (hydroxymethyl) amino-methane, porcine pancreatic trypsin (PPT), Tween ${ }^{\circledR} 20$, and urea were acquired from Sigma Co. Ltd. (St. Louis, MO, USA). Acetone, acetonitrile (ACN), dichloromethane (DCM), N,N-dimethyl formamide (DMF), piperidine, 
and toluene of High-Performance Liquid Chromatography (HPLC) grade were used. Purified distilled water acquired from a Milli-Q water purification system was used in all the experiments.

\subsection{Template Synthesis}

The peptide segments, such as PPT ${ }^{107-116}$ (KLSSPATLNS), PPT ${ }^{145-155}$ (KSSGSSYPSLL), PPT $^{169-178}$ (KSSYPGQITG), and PPT ${ }^{233-245+G}$ (NYVNWIQQTIAANG), were produced through the Fmoc (fluorenylmethoxycarbonyl) solid-phase peptide synthesis approach using a Discover SPPS Microwave Peptide synthesizer (Kohan Co. Ltd., Taipei, Taiwan) available at the National Dong Hwa University (Hualien, Taiwan) [22].

\subsection{Preparation of PCIs on $M P s$}

\subsubsection{Construction of $\mathrm{Fe}_{3} \mathrm{O}_{4} @$ APTMS-GA}

The synthesis of the $\mathrm{Fe}_{3} \mathrm{O}_{4}$ precursor, and subsequent immobilization of amine functionality, $\mathrm{Fe}_{3} \mathrm{O}_{4} @$ APTMS, were performed as described previously $[23,24]$. Further, glutaraldehyde (GA) was coupled with $\mathrm{Fe}_{3} \mathrm{O}_{4} @$ APTMS to construct stable secondary amine nanoparticles. Briefly, $100 \mathrm{mg}$ of $\mathrm{Fe}_{3} \mathrm{O}_{4}$ @APTMS was initially placed in $50 \mathrm{~mL}$ of ACN and subjected to ultrasonication for $30 \mathrm{~min}$. Then, $162 \mu \mathrm{L}$ of GA was added to the mixture. Further, a few drops of acetic acid were added to maintain the weakly acidic state of the reaction mixture, and stirring was performed for $2 \mathrm{~h}$. Subsequently, $200 \mathrm{mg}$ of $\mathrm{NaBH}_{3} \mathrm{CN}$ were added, and vigorous stirring was executed for another $2 \mathrm{~h}$ to make the reaction mixture weakly alkaline. Finally, the resultant particles were recovered with a strong magnet, washed several times with a solvent mixture of $\left(\mathrm{H}_{2} \mathrm{O}: \mathrm{ACN}=1: 1\right)$, and dried under vacuum.

\subsubsection{Synthesis of $\mathrm{Fe}_{3} \mathrm{O}_{4} @ A P T M S-G A-A c r y l a t e$}

To prepare $\mathrm{Fe}_{3} \mathrm{O}_{4} @$ APTMS-GA-acrylate, $300 \mathrm{mg}$ of GA-modified MPs were initially dispersed in $25 \mathrm{~mL}$ of dry DCM and stirred for $15 \mathrm{~min}$ after adding TEA $(0.48 \mathrm{~mL})$. Then, acryloyl chloride $(0.3 \mathrm{~mL}, 3.75 \mathrm{mmol})$ was added in a drop-wise manner to the mixture at $0{ }^{\circ} \mathrm{C}$ under $\mathrm{N}_{2}$ purge and stirred for $24 \mathrm{~h}$. Finally, the resultant product was washed with DCM and dried under vacuum.

\subsubsection{Preparation of PCIMPs}

To prepare PCIMPs, initially, $211.2 \mathrm{mg}$ of $N$, $N^{\prime}$-ethylene bisacrylamide (EBAA), $56.4 \mathrm{mg}$ of benzyl acrylamide (BAA), and $25.2 \mathrm{mg}$ of acrylamide (AA) were dissolved in a solvent mixture containing $16 \mathrm{~mL}$ of PBS (pH-7.6, $20 \mathrm{mM}$ ) and $2 \mathrm{~mL}$ of ethanol. Then, $7.5 \mu \mathrm{mol}$ of template molecules (PPT ${ }^{107-116}, \mathrm{PPT}^{145-155}$, PPT ${ }^{169-178}$, and $\mathrm{PPT}^{233-245+\mathrm{G}}$ ) were dissolved separately in $20 \mathrm{~mL}$ of a solvent mixture of TFE and PBS at a ratio of 7:3 to exhibit the helical structure in the polymerization system. Further, the above two reaction mixtures were mixed after a while, and $90 \mathrm{mg}$ of $\mathrm{Fe}_{3} \mathrm{O}_{4} @$ APTMS-GA-Acrylate was added to make a pre-self-assembly reaction mixture. Then, $240 \mu \mathrm{L}(10 \%, w / w)$ of ammonium persulfate and $90 \mu \mathrm{L}(5 \%, w / v)$ of TEMED were added to the reaction and stirred for $24 \mathrm{~h}$ in the presence of $\mathrm{N}_{2}$ at RT. The template removal was performed based on previous studies $[25,26]$. According to the following articles, acetic acid as a solvent disrupts the electrostatic interactions between the template and the polymer matrix, which can be separated. Notably, the template removal process could be achieved in few minutes. Finally, the polymer-MPs were obtained and washed with $25 \mathrm{mM}$ urea (aq) containing $5 \%$ acetic acid and $0.5 \%$ tween- 20 to remove the template. Subsequently, the pore structures formed after the removal of the four different templates were denoted as PCIMPs ${ }^{107-116}$, PCIMPs $^{145-155}$, PCIMPs ${ }^{169-178}$, and PCIMPs ${ }^{233-245+G}$, respectively. 


\subsection{Determination of Binding Affinities of PCIMPs}

Notably, the binding experiments were carried out in $10 \mathrm{~min}$ to avoid adsorption at non-specific binding sites on PCIMPs. Briefly, $10 \mathrm{mg}$ of PCIMPs was added to PBS (pH-7.6, $20 \mathrm{mM}$ ) containing PPT at different concentrations $(0.125,0.25,0.5,1$, and $1.5 \mathrm{mg} / \mathrm{mL})$ and the resulting mixture was shaken for $10 \mathrm{~min}$. Then, $200 \mu \mathrm{L}$ of supernatant was collected and measured by Fluorescence Microplate Reader at $\lambda$ ex $/ \lambda \mathrm{em}=290 \mathrm{~nm} / 350 \mathrm{~nm}$. Each experiment was repeated three times, and the results of the binding studies were evaluated using the Scatchard Equation (1) [27-29].

$$
[\mathrm{RL}] /[\mathrm{L}]=\left(\mathrm{B}_{\max }-[\mathrm{RL}]\right) / \mathrm{K}_{\mathrm{d}}
$$

where [L] is the concentration of PPT in the solution, [RL] is the concentration of bound PPT, $\mathrm{B}_{\max }$ denotes the maximum number of binding sites, and $\mathrm{K}_{\mathrm{d}}$ is the dissociation constant of the ligand.

\subsection{Activity Assay of PPT and Immobilized PPT (PPT/PCIMPs)}

The catalytic activity of PPT and PPT/PCIMPs was measured using the HPLC method. $\mathrm{N}$-benzoyl-L-arginine ethyl ester (BAEE) was utilized as the starting material, while the product was $N$-Benzoyl-L-Arginine (BA), which was observed with time. The percentage of hydrolysis rate was calculated using the following Equation (2):

$$
\text { Hydrolysis rate }(\%)=\frac{\text { Product area ratio }}{(\text { Starting area ratio }+ \text { product area ratio })} \times 100
$$

For determining the catalytic activity of PPT, initially, $1 \mathrm{~mL}$ mixtures possessing different BAEE concentrations $(0.5,1.0$, and $1.5 \mathrm{mM})$ were prepared using $50 \mathrm{mM}$ of Tris$\mathrm{HCl}$ buffer, with a pH equal to 7.6. Then, $20 \mu \mathrm{L}$ of $1 \mathrm{mM} \mathrm{HCl}$ containing $30 \mu \mathrm{g}$ PPT was formulated. The assay was started by adding $20 \mu \mathrm{L}$ of $1 \mathrm{mM} \mathrm{HCl} / 30 \mu \mathrm{g}$ PPT to $1 \mathrm{~mL}$ mixtures with the three BAEE concentrations mentioned above, respectively. For every min, $40 \mu \mathrm{L}$ of the solution was collected from the reaction mixture and dissolved in $500 \mu \mathrm{L}$ of ACN: buffer $=15: 85$, and $99.5 \mu \mathrm{L}$ of the resultant solution was injected for HPLC detection until the end of the reaction.

\subsection{PPT/PCIMPs Activity Assay}

Briefly, $10 \mathrm{mg}$ of each PPT/PCIMPs were separately added to $8.8 \mathrm{~mL}$ of the BAEE solutions $(0.5,1.0$, and $1.5 \mathrm{mM})$, and for every $\mathrm{min}, 80 \mu \mathrm{L}$ of that solution were separated from the mixture and dissolved in $1 \mathrm{~mL}$ of $\mathrm{ACN}$ : buffer $=15: 85$. From this, $99.5 \mu \mathrm{L}$ of the solution was collected for HPLC detection until the end of the reaction. The same procedure was also carried out for the reusability test.

An intelligent, high-performance liquid chromatography (HPLC, model L7100, Hitachi, Tokyo, Japan) set-up equipped with a UV detector (Hitachi model L-2420, Tokyo, Japan), an autosampler (Hitachi L-2200, Tokyo, Japan), and a Vercopak-RP C18 column (Vercotech Corp., Taipei, Taiwan) was used to determine the purity of peptides and for performing the kinetic analysis of the immobilized enzyme. In the hydrolysis test, the mobile phase of HPLC was composed of $0.38 \mathrm{~mL}$ of phosphoric acid, $0.47 \mathrm{~mL}$ of triethylamine, and $1 \mathrm{~L}$ of DI- $\mathrm{H}_{2} \mathrm{O}$. The solution was then adjusted to $\mathrm{pH} 2.4$ with $\mathrm{NaOH}$ and $\mathrm{HCl}$. The ultraviolet wavelength was set at $214 \mathrm{~nm}$.

\subsection{Determination of Kinetic Constants of PPT and PPT/PCIMPs}

The kinetic parameters of PPT and PPT/PCIMPs were evaluated from the MichaelisMenten plot obtained from the following Equation (3),

$$
v=\frac{V_{\max }[\mathrm{S}]}{\left(K_{m}+[\mathrm{S}]\right)}
$$


where $v$ is the reaction velocity at [S], $V_{\max }$ is the maximum rate of the reaction, $K_{m}$ is the Michaelis half-saturation constant, and [S] is the concentration of the substrate.

The turnover number $\left(k_{c a t}\right)$ was calculated using the below Equation (4).

$$
k_{\text {cat }}=V_{\max } /[E]
$$

where $[E]$ is the enzyme concentration [13].

\section{Results and Discussions}

\subsection{Rational Selection of the Template}

The template for the imprinting was chosen considering the following parameters: (i) Peptide segments from the flank part of the PPT spatial structure were selected as the template. Due to five disulfide linkages connected among PPT, the choice of peptide segments able to influence catalysis is limited. (ii) The length of the peptide segments in the template is a significant parameter. For instance, short peptide residues form flexible structures that can help the imprinting and protein-rebinding processes [19,30]. Therefore in this study, four PPT peptides, specifically PPT ${ }^{107-116}, \mathrm{PPT}^{145-155}, \mathrm{PPT}^{169-178}$, and $\mathrm{PPT}^{233-245}$, were chosen. The locations of these segments are shown in Figure 2. At one end of the PPT $^{233-245}$ peptide, a glycine $(G)$ residue was added to make a stable peptide chain with flexibility [31,32].

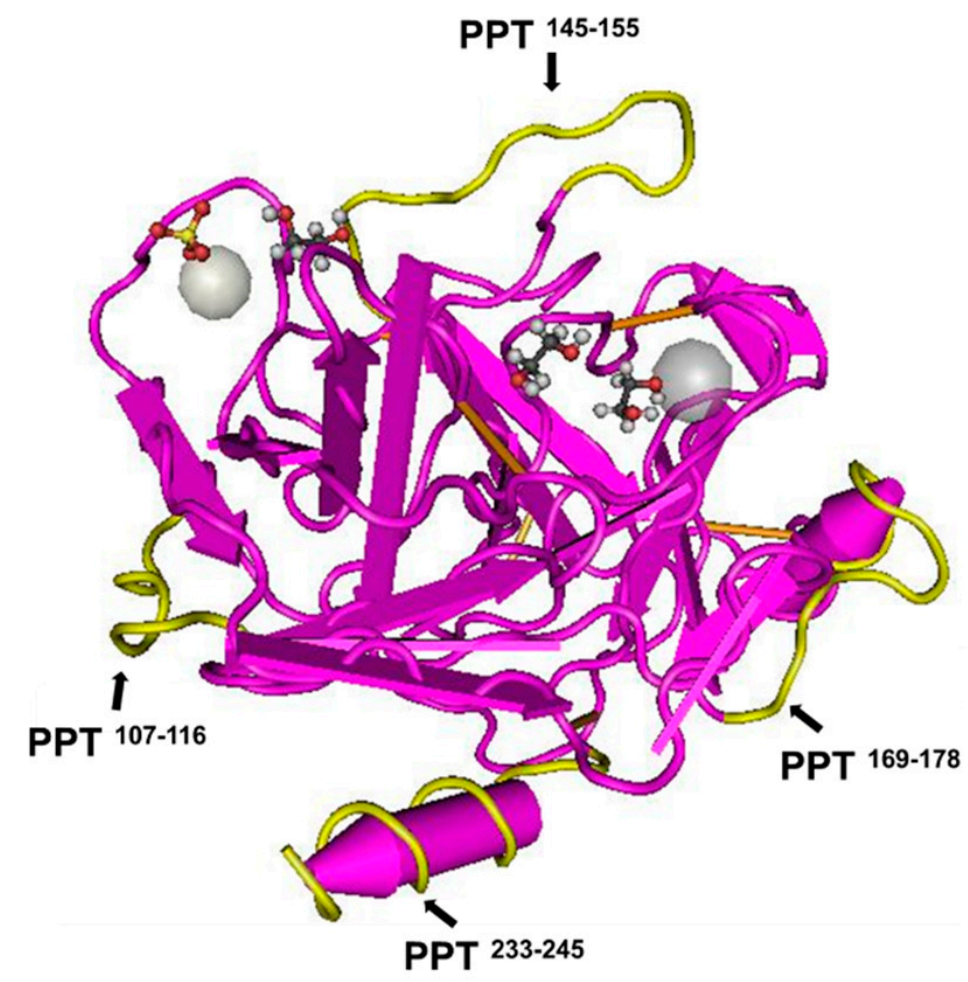

Figure 2. The structure of porcine pancreatic trypsin (cylinder: $\alpha$-helix; arrow: $\beta$-sheet). The selected sequences are in yellow. These segments consist of the series: i.e., $\mathrm{PPT}^{107-116}, \mathrm{PPT}^{145-155}, \mathrm{PPT}^{169-178}$, and PPT $233-245$. The crystal structure of PPT was reproduced from http:/ / www.ncbi.nlm.nih.gov / and PDB ID: 1 S81 [33].

\subsection{Analysis of the Template}

Furthermore, the template was synthesized using a CEM Discover Microwave Synthesizer (Kohan Co., Taipei, Taiwan) at National Dong Hwa University (Hualien, Taiwan). The peptide segments PPT ${ }^{107-116}, \mathrm{PPT}^{145-155}$, $\mathrm{PPT}^{169-178}$, and $\mathrm{PPT}^{233-245+\mathrm{G}}$ were selected as templates. Initially, these segments were fabricated using the Fmoc solid-phase peptide synthesis [22]. Further, the purity of the template molecules was confirmed by HPLC 
equipped with an RP-18 (flow rate- $1 \mathrm{~mL} / \mathrm{min}$ ). Among the selected peptide segments, $\mathrm{PPT}^{107-116}$ and $\mathrm{PPT}^{169-178}$ showed a purity higher than $96 \%$. Contrarily, the other two segments, $\mathrm{PPT}^{145-155}$ and $\mathrm{PPT}^{233-245+\mathrm{G}}$, had a lower purity of around $88 \%$, which could be attributed to their longer length, leading to a difficulty in the purification of those peptide segments [34]. Further, the molecular mass of the template was analyzed using a MatrixAssisted Laser Desorption/Ionization-Time of Flight (MALDI/TOF) mass spectrometer (MS) (Bruker, Bremen, Germany) with a matrix consisting of 2,5-dihydroxybenzoic acid (DHB). The reported $\mathrm{m} / \mathrm{z}$ values of PPT ${ }^{107-116}$, $\mathrm{PPT}^{145-155}$, $\mathrm{PPT}^{169-178}$, and PPT ${ }^{233-245+G}$ were observed at 1017.69, 1125.56, 1037.39, and 1614.24 [M + Na ${ }^{+}$, respectively. Further, the peptide segment $\mathrm{PPT}^{233-245+\mathrm{G}}$ was analyzed with a (JASCO, J-715, Tokyo, Japan) circular dichroism (CD) spectrometer to validate the helix structure in the mixtures of buffer and TFE (Figure 3). Usually, the helical peptides possess negative bands at 208 and $225 \mathrm{~nm}$ in a mixture of PBS and TFE, while the peptides with random coil structures show negative bands at $200 \mathrm{~nm}$ in PBS [35]. After that analysis, the selected PPT peptide segments were used to generate helix cavities using the PCIMPs-based approach.

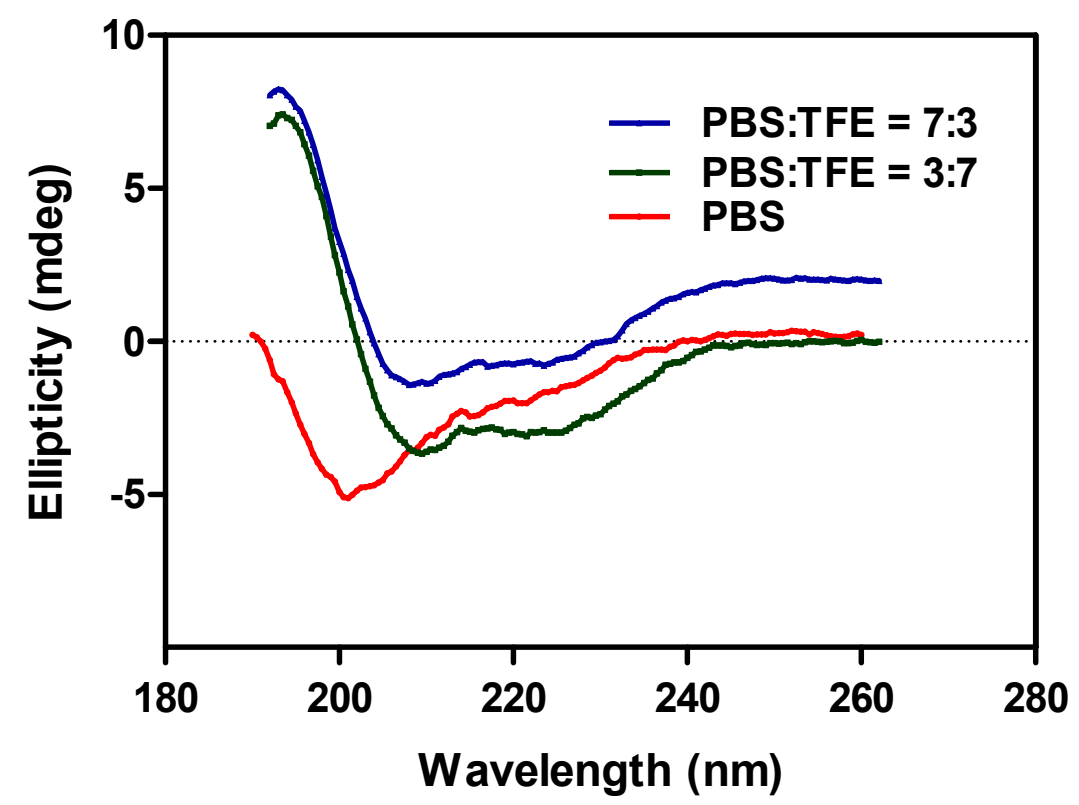

Figure 3. The circular dichroism (CD) spectrum of the PPT ${ }^{233-245+G}$ segment in different solvent systems.

\subsection{Characterization of MPs and PCIMPs \\ 3.3.1. FTIR Analysis}

A Fourier-transform infrared spectrometer (FTIR, Bruker TENSOR 27, Ettlingen, Germany) was employed to examine the successive surface modifications on MPs (Figure 4). The peaks at $586 \mathrm{~cm}^{-1}$ and $3444 \mathrm{~cm}^{-1}$ can be ascribed to Fe-O stretching vibration and O-H stretching of $\mathrm{Fe}_{3} \mathrm{O}_{4}$ (Figure 4a). The characteristic peaks of silanol groups (Si-O-H) on the surface of $\mathrm{Fe}_{3} \mathrm{O}_{4}$ at $1030 \mathrm{~cm}^{-1}$, as well as at $1100 \mathrm{~cm}^{-1}$, and the peak at $3421 \mathrm{~cm}^{-1}$ can represent the characteristic peaks of $\mathrm{NH}_{2}$ (primary amine) of APTMS, indicating the successful modification of the $\mathrm{Fe}_{3} \mathrm{O}_{4}$ nanoparticles surface with amine groups (Figure 4b) [36-38]. Additionally, the peaks near of $3413 \mathrm{~cm}^{-1}$ can represent the existence of the $\mathrm{N}-\mathrm{H}$ functional group, and no peak at $1739 \mathrm{~cm}^{-1}$ can indicate the $\mathrm{C}=\mathrm{O}$ group at both ends of the glutaraldehyde molecule reacted with $\mathrm{NH}_{2}$, attributed to the established stable secondary structure. The secondary amine-modified iron nanoparticles are more reactive than the primary amine because the inductive effect of secondary amine makes them more stable compared to the primary amine (Figure $4 \mathrm{c}$ ). The peak at $1619 \mathrm{~cm}^{-1} \mathrm{can}$ be ascribed to the characteristic peak of $C=C$, indicating successful acrylation of the MPs (Figure 4d) [39]. 


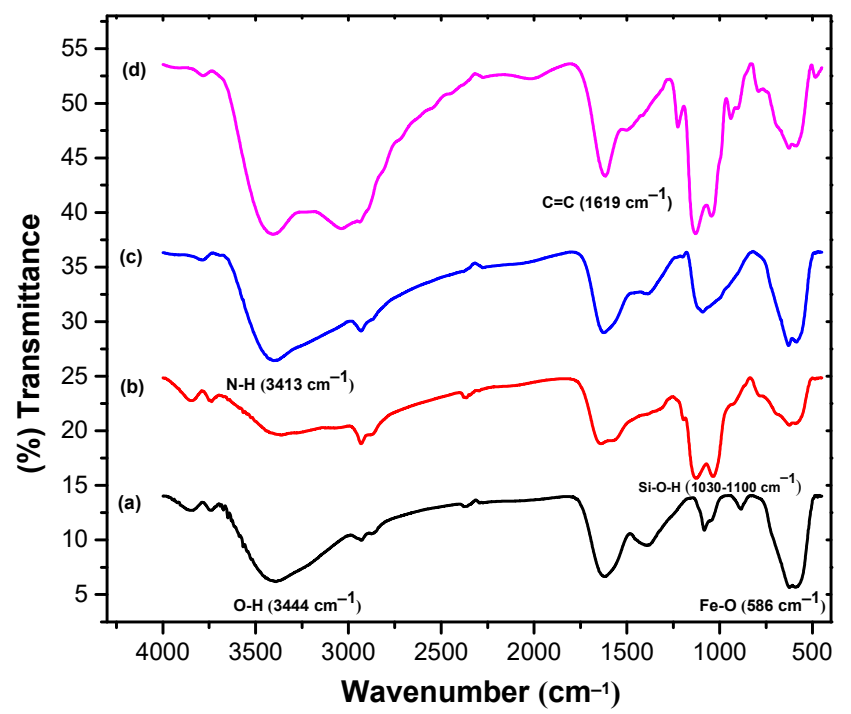

Figure 4. FTIR spectra of (a) $\mathrm{Fe}_{3} \mathrm{O}_{4}$, (b) $\mathrm{Fe}_{3} \mathrm{O}_{4} @ \mathrm{APTMS}$, (c) $\mathrm{Fe}_{3} \mathrm{O}_{4} @ \mathrm{APTMS}-\mathrm{GA}$, and (d) $\mathrm{Fe}_{3} \mathrm{O}_{4} @$ APTMS-GA-acrylate.

\subsubsection{FE-SEM Analysis}

The surface morphology of various MPs and PCIMPs was analyzed using a Field Emission Scanning Electron Microscope (FE-SEM, JEOL JSM-7000F/JEOL Ltd., Tokyo, Japan) (Figure 5). As a result, it was observed that the fabricated $\mathrm{Fe}_{3} \mathrm{O}_{4}$ particles were spherical, showing a uniform size distribution with an average size of $\sim 237 \mathrm{~nm}$ (Figure 5a). Further, APTMS immobilization on $\mathrm{Fe}_{3} \mathrm{O}_{4}$ nanoparticles resulted in substantial changes in the size and shape of those MPs, having increased their average size to $278 \mathrm{~nm}$ (Figure 5b). The subsequent immobilization of glutaraldehyde on the MPs resulted in an increase in their average size to $\sim 309 \mathrm{~nm}$ (Figure $5 \mathrm{c}$ ). Notably, a slight aggregation can be observed after the successive surface modification on the MPs. This could be because nanoparticles treated with different solvents and dry samples were collected after the surface modification. The dry power shows strong aggregation, as reported in previous studies [40]. Further, the acrylate monomer conjugation with MPs resulted in an average size of $\sim 323 \mathrm{~nm}$ (Figure 5d). Amongst all PCIMPs, the PCIMPs ${ }^{107-116}$, PCIMPs ${ }^{145-155}$, and PCIMPs ${ }^{169-178}$ have shown similar size at $\sim 370 \mathrm{~nm}$, whereas PCIMPs ${ }^{233-245+G}$ were comparatively larger at $\sim 408 \mathrm{~nm}$ (Figure 5e-h).
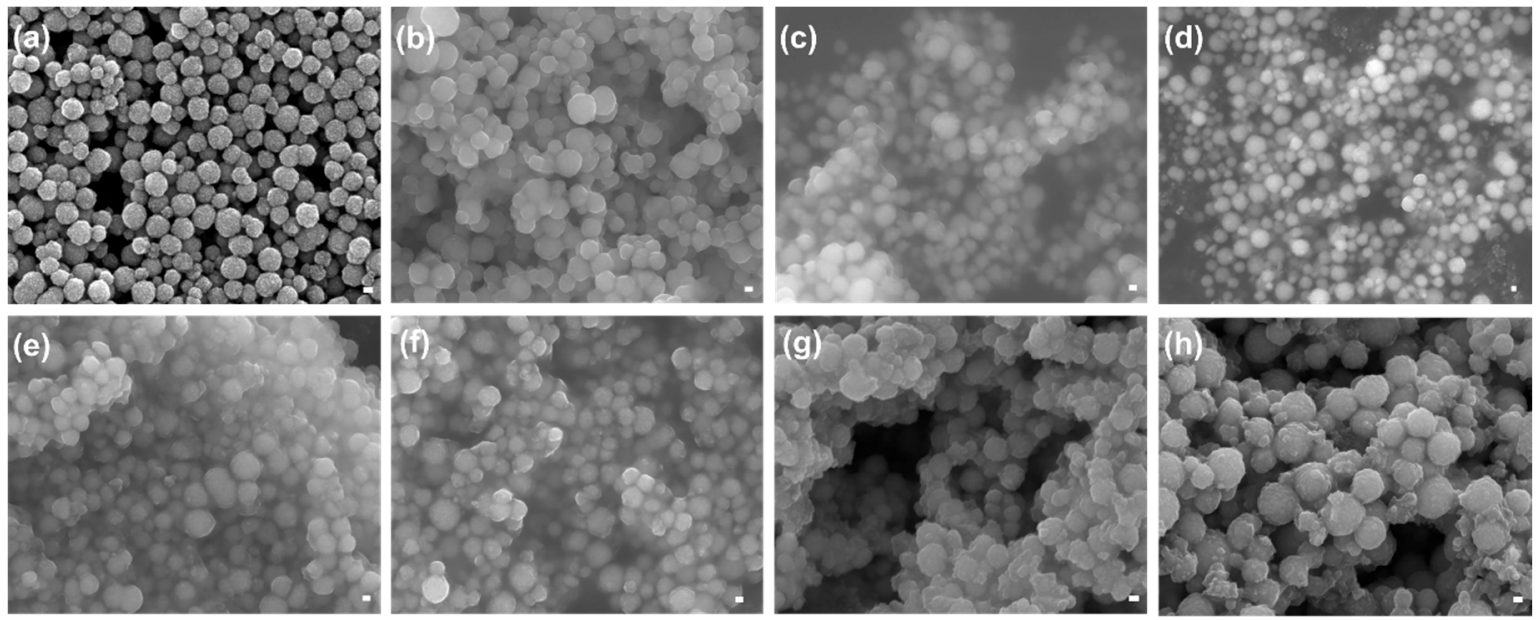

Figure 5. FE-SEM images of (a) $\mathrm{Fe}_{3} \mathrm{O}_{4}$, (b) $\mathrm{Fe}_{3} \mathrm{O}_{4} @$ APTMS, (c) $\mathrm{Fe}_{3} \mathrm{O}_{4} @$ APTMS-GA, (d) $\mathrm{Fe}_{3} \mathrm{O}_{4} @$ APTMS-GA-acrylate, (e) PCIMPs ${ }^{107-116}$, (f) PCIMPs ${ }^{145-155}$, (g) PCIMPs ${ }^{169-178}$, and (h) PCIMPs ${ }^{233-245+G}$ (Scale bar: 100 nm). 


\subsection{Binding Studies of PCIMPs}

For comparison, the binding affinities of the PPT to each PCIMPs were measured by the linear regression curve based on the Scatchard equation. As shown in Table 1, the PCIMPs ${ }^{233-245+G}$ had the lowest $K_{d}$ value $(0.21 \mu \mathrm{M})$ of all the PCIMPs. It was observed from the results that the $K_{d}$ values showed a decreasing trend with an increase in the number of peptide residues. Therefore, the higher the number of peptide segments in the template, the better the observed binding affinities. For instance, for the 14-mer peptide, the $K_{d}$ was $0.21 \mu \mathrm{M}$, and it showed better affinity when compared to the 10 and 11-mer peptides [19]. Similarly, for PCIMPs ${ }^{145-155}$, the $K_{d}$ value was $0.38 \mu \mathrm{M}$, and it presented a better affinity than that of a 10-mer peptide. On the other hand, both PCIMPs ${ }^{107-116}$ and PCIMPs ${ }^{169-178}$ have shown a similar number of peptide residues in the template. In this case, affinities of the PPT to PCIMPs were more closely related to the molecular weight of the template residues. For example, the $\mathrm{K}_{\mathrm{d}}$ value of the PCIMPs ${ }^{169-178}$ was $0.55 \mu \mathrm{M}$, which showed a better binding affinity than PCIMPs ${ }^{107-116}(0.65 \mu \mathrm{M})$.

Table 1. Binding affinity values of various PCIs on magnetic particles (PCIMPs) to PPT.

\begin{tabular}{ccccc}
\hline MPs & PCIMPs $^{\text {107-116 }}$ & PCIMPs $^{\text {145-155 }}$ & PCIMPs $^{\text {169-178 }}$ & PCIMPs $^{\text {233-245+G }}$ \\
\hline Residue & 10 & 11 & 10 & 14 \\
{$\left[\mathrm{~K}_{\mathrm{d}}\right] \mu \mathrm{M}$} & 0.65 & 0.38 & 0.55 & 0.21 \\
{$\left[\mathrm{~B}_{\max }\right] \mathrm{nM}$} & 0.75 & 1.11 & 0.95 & 1.11 \\
$\mathrm{~B}_{\max } / \mathrm{K}_{\mathrm{d}}$ & 1.15 & 2.92 & 1.73 & 5.29 \\
\hline
\end{tabular}

Previously, Griffete and colleagues developed a magnetic-protein imprinted polymer (M-PIP) by combining photopolymerization with a grafting approach onto surfacefunctionalized MPs. The authors demonstrated that the green fluorescent proteins were bound to MIPs in less than $2 \mathrm{~h}$ with a high affinity $\left(\mathrm{K}_{\mathrm{d}}=0.29 \mu \mathrm{M}\right)$ [41]. In another study, MIPs were synthesized using a solid-phase approach on metal chelate functionalized glassbeads to immobilize trypsin using its surface histidine. Although less cross-reactivity with other proteins was observed, the dissociation constant value of the MIP-trypsin complex was $0.237 \mu \mathrm{M}$ [42], with a lagging binding capacity. Notably, in this study, the PCIs developed on the surface of MPs create recognition sites that are complementary to the protein conformational structure and, therefore, significantly increase the specificity toward the targeted protein. The best binding performance of PCIMPs ${ }^{233-245+G}$ occurred in $10 \mathrm{~min}$ with a high affinity $\left(K_{d}=0.21 \mu \mathrm{M}\right)$. Upon a comprehensive evaluation of binding affinities and absorption time, it was apparent that conformational imprints on MPs acquired better results in these protein-imprinted particles. Together, our findings indicated a higher affinity of protein (PPT) to PCIMPs ${ }^{233-245+G}\left(K_{d}=0.21 \mu \mathrm{M}\right)$, in comparison to the other MIPs grafting methods.

\subsection{Kinetic Parameters of PPT and PPT/PCIMPs}

In addition, the PCIMPs bound to PPT exhibited excellent catalytic activity. To demonstrate this aspects, the kinetic parameters of PPT and PPT/PCIMPs were explored by varying the BAEE substrate concentration $(0.5-1.5 \mathrm{mM})$. They were then calculated using the Michaelis-Menten plot (Figure 6a). As shown in Table 2, among all the PPT/PCIMPs, PPT/PCIMPs ${ }^{233-245+G}$ had the best kinetic parameters. The $K_{m}$ value of PPT $(0.36 \mathrm{mM})$ was almost similar to that of the PPT/PCIMPs ${ }^{233-245+G}(0.42 \mathrm{mM})$, which could be due to the high feasibility of forming an enzyme-substrate complex, and also a lower diffusion restraint imposed on the flow of the substrate and product molecules from the grafted polymer matrix of the MPs [43,44]. The $V_{\max }$ values were found to be $3.2 \times 10^{-3} \mathrm{mMs}^{-1}$ and $1.47 \times 10^{-3} \mathrm{mMs}^{-1}$ for PPT and PPT/PCIMPs ${ }^{233-245+G}$, in which the $V_{\max }$ was decreased for PPT/PCIMPs when compared to the free enzyme. The plausible reason might be due to the created steric hindrances that restrict the substrates' transport, enhance diffusional creation limitations, and decrease the enzyme's catalytic properties. These conclusions are in agreement with the results reported literature [45,46]. 


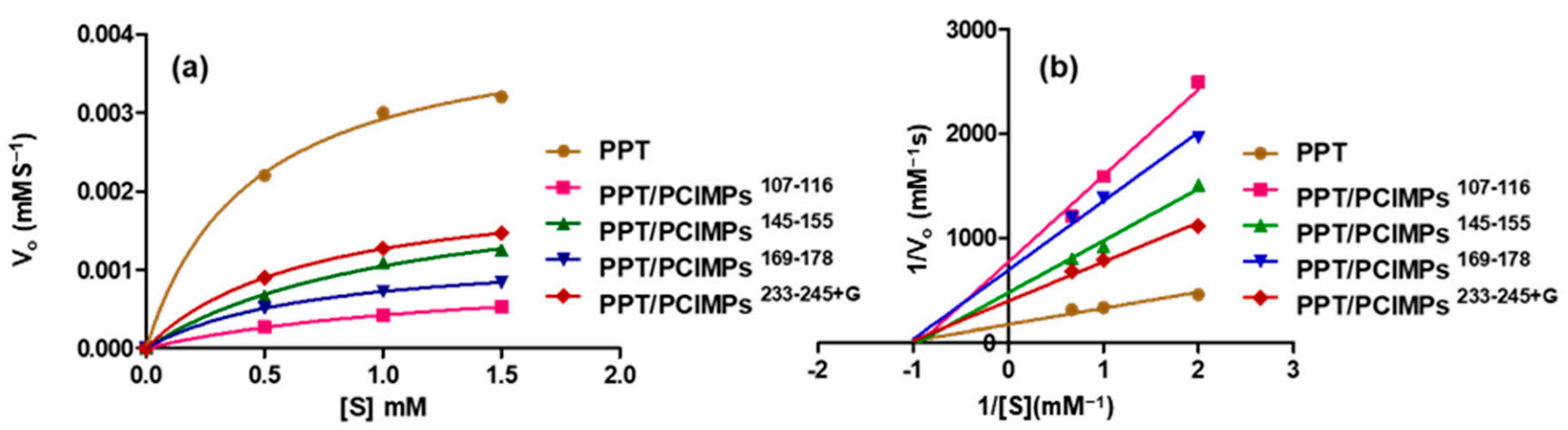

Figure 6. (a) Michaelis-Menten and (b) Lineweaver-Burk plots of PPT and PPT/PCIMPs obtained with various N-benzoylL-arginine ethyl ester (BAEE) solutions $(1.5,1,0.5 \mathrm{mM})$. Note: The standard deviation for the Michaelis-Menten kinetics plot of PPT in different concentration $(1.5 \mathrm{mM}$ to $0.5 \mathrm{mM})$ is $1 \times 10^{-4}$ whereas and PPT/PCIMPs $233-245+\mathrm{G}$ is $1.41067 \times 10^{-5}$, $7.2111 \times 10^{-6}$, and $5.50757 \times 10^{-6}$ for $(1.5,1$, and $0.5 \mathrm{mM})$.

Table 2. Kinetic parameters obtained from the Michaelis-Menten plot.

\begin{tabular}{cccccc}
\hline MPs & PPT & PPT/PCIMPs $^{\text {107-116 }}$ & PPT/PCIMPs $^{\text {145-155 }}$ & PPT/PCIMPs $^{\text {169-178 }}$ & PPT/PCIMPs $^{\text {233-245+G }}$ \\
\hline$V_{\text {max }}\left(\mathrm{mM} \mathrm{s}^{-1}\right)$ & $3.2 \times 10^{-3}$ & $0.53 \times 10^{-3}$ & $1.25 \times 10^{-3}$ & $0.84 \times 10^{-3}$ & $1.47 \times 10^{-3}$ \\
{$\left[K_{m}\right] \mathrm{mM}^{-3}$} & 0.36 & 0.52 & 0.46 & 0.44 & 0.42 \\
$k_{\text {cat }}\left(\mathrm{s}^{-1}\right)$ & 2.6 & 0.62 & 0.99 & 0.78 & 1.16 \\
$k_{\text {cat }} / K_{m}\left(\mathrm{mM}^{-1} \mathrm{~s}^{-1}\right)$ & 7.32 & 1.19 & 2.15 & 1.77 & 2.79 \\
\hline
\end{tabular}

Note: PPT= porcine pancreatic alpha-trypsin, PPT/PCIMPs = immobilized PPT.

Respectively, it was observed that the $k_{\text {cat }}$ value of PPT/PCIMPs ${ }^{233-245+G}$ was lower than that of PPT. The decrease of $k_{\text {cat }}$ values upon immobilization of enzymes are frequently reported $[13,47,48]$. These findings suggest a limited diffusion of the substrate to the active site and higher structural rigidity of the immobilized PPT. Our results are quite comparable and in agreement with the ones reported in the literature [47-50]. Furthermore, the trypsin inhibition by PCIMPs was investigated by performing enzyme assays in the Tris-HCl buffer at $\mathrm{pH}$ 6.2, using BAEE as the substrate at various concentrations. The Lineweaver Burk plot $\left(1 / \mathrm{V}_{\mathrm{o}}\right.$ versus $\left.1 / \mathrm{S}\right)$ is as shown in Figure $6 \mathrm{~b}$. It reveals that the PCIMPs exhibited non-competitive inhibition towards trypsin, in which the PCIMPs acted as inhibitors, while the BAEE functioned as a substrate. In non-competitive inhibition, the respective inhibitors bind to the free enzyme and the enzyme-substrate complex with the same affinity. Further, the inhibitor reduces the activity of the enzyme and binds equally well to the substrate $[51,52]$.

\subsection{Reusability}

Additionally, the reusability of PPT/PCIMPs was examined. Initially, $10 \mathrm{mg}$ of PPT/PCIMPs ${ }^{145-155}$ was added to $8.8 \mathrm{~mL}$ of a $1.5 \mathrm{mM}$ BAEE solution (50 mM Tris- $\mathrm{HCl}$ buffer, $\mathrm{pH}$ 7.6). The product concentration was monitored using HPLC. The test was conducted consecutively four times. It was observed from the results that the PPT/PCIMPs retained $90 \%$ of activity in $540 \mathrm{sec}$ in the first cycle; however, in the subsequent cycles, it slightly dropped. The activity of the protein sustained after four cycles is as shown in Figure 7. 


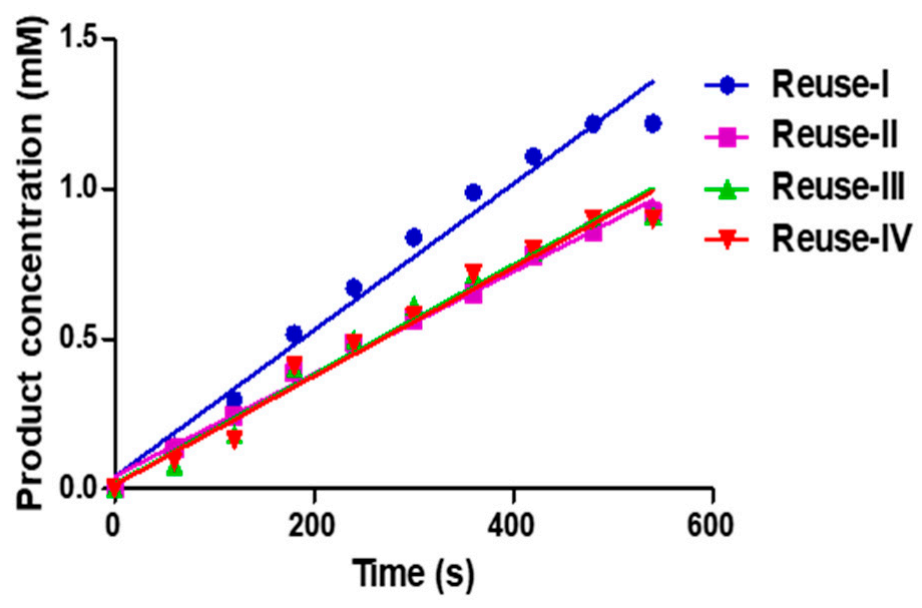

Figure 7. Reusability of PPT/PCIMPs ${ }^{145-155}$.

\subsection{Comparison Studies of the Proposed PPT/PCIMPs with Other Methods}

The catalytic hydrolysis performance of the fabricated PPT/PCIMPs was compared to previous studies (Table 3). For example, Atacan and colleagues modified the surface of $\mathrm{Fe}_{3} \mathrm{O}_{4}$ nanoparticles with gallic acid. According to their research, $K_{m}$ values of trypsin and immobilized trypsin were 5.1 and $7.88 \mathrm{mM}$, respectively, indicating that the immobilized trypsin has less affinity for the substrate, which might be attributed to the loss of enzyme flexibility. Although immobilized trypsin retained $92 \%$ of its initial activity after four months of storage at $4{ }^{\circ} \mathrm{C}$, there was a dramatic decrease in its activity after being reused eight consecutive times [49]. In another study, trypsin was immobilized on polymer and grafted magnetic beads, in which the $K_{m}$ for immobilized trypsin was found to be $13.6 \mathrm{mM}$, 1.4-fold higher than free trypsin, while $V_{\max }$ value was found to be $3946 \mathrm{U} / \mathrm{mg}$, 1.5 -fold lower than for the free trypsin, indicating that a change in the affinity of the enzyme towards the substrate occurred upon its immobilization [50]. In different work, by Bayramoglu and colleagues, polymer grafted magnetic beads were activated with glutaraldehyde for the immobilization of trypsin on affinity ligands attached to the beads' surface. Moreover, the reusability and activity were relatively good in this study when compared to the above work. The $K_{m}$ and $V_{\max }$ values obtained for the immobilized trypsin were of $16.8 \mathrm{mM}$ and $5115 \mathrm{U} / \mathrm{mg}$, 1.8-fold higher and 1.5-fold lower than free trypsin, respectively. The $K_{m}$ values could be explained by the fact that there existed conformational changes during enzyme immobilization [53].

Table 3. Comparison studies of proposed PPT/PCIMPs with other methods.

\begin{tabular}{|c|c|c|c|c|c|}
\hline Trypsin/Immobilized Trypsin & $K_{m}$ & $V_{\max }$ & $k_{\text {cat }}\left(\mathrm{s}^{-1}\right)$ & $k_{c a t} / K_{m}\left(\mathrm{mM}^{-1} \mathrm{~s}^{-1}\right)$ & Reference \\
\hline BPT/Immobilized BPT & $5.1 / 7.88 \mathrm{mM}$ & $23 / 18.3 \mathrm{mM} \mathrm{min}^{-1}$ & - & - & [42] \\
\hline BPT/Immobilized BPT & $9.7 / 13.6 \mathrm{mM}$ & $5890 / 3946 \mathrm{U} / \mathrm{mg}$ & - & $607 / 290$ & [43] \\
\hline BPT/Immobilized BPT & $9.3 / 16.8 \mathrm{mM}$ & $7345 / 5115 \mathrm{U} / \mathrm{mg}$ & - & - & [44] \\
\hline PPT and PPT/PCIMPs ${ }^{233-245+G}$ & $0.36 / 0.42 \mathrm{mM}$ & $3.2 \times 10^{-3} / 1.47 \times 10^{-3} \mathrm{mM} \mathrm{s}^{-1}$ & $2.6 />1.16$ & $7.32 / 2.79$ & This study \\
\hline
\end{tabular}

Abbreviations: Bovine Pancreas Trypsin (BPT), Porcine Pancreatic Trypsin (PPT), Note: U is defined as $\mu \mathrm{mol}$.

Upon a comprehensive evaluation of kinetic parameters, it was evident that the elegant helical cavities imprinting strategy created recognition sites on the MPs surface, in which the enzymes were tightly bound. Moreover, it was achieved an improved catalytic hydrolysis in comparison to other previous studies. The best performance of PPT/PCIMPs for hydrolysis of BAEE had the following values for the kinetic parameters $K_{m}, V_{\max }$, and $k_{\text {cat }}$ values were $0.42 \mathrm{mM}, 1.4 \mu \mathrm{M} \cdot \mathrm{s}^{-1}$, and $1.16 \cdot \mathrm{s}^{-1}$. Additionally, PPT/PCIMPs-imprinted materials exhibited stable catalytic activity and reusability. 


\section{Conclusions}

In conclusion, a state-of-the-art method for point immobilization of enzymes on magnetic particles is accomplished. To maintain the catalytically competent state of an enzyme, an immobilized enzyme at a maximum degree of freedom is the ultimate choice. Our systems operate by binding enzyme partially and maintaining the remaining part of the enzyme free. The combination of site fixation with the use of conformation-specific PCIMPs could boost the catalytic process in many enzymes. Moreover, the experimental results also indicated the inhibition effect on capturing at the $\alpha$-helix region to interfere with catalysis flexibility. The $K_{m}$ of PPT/PCIMPs ${ }^{233-245+G}$ was slightly higher than that of PPT, resulting in lower diffusion limitations of the substrate and product molecules from the polymer matrix to forming an enzyme-substrate complex. Consequently, this method is an appropriate choice for realizing the relationship between each segment's flexibility and catalytic activity. We thus believe the PCIMPs strategy can be more widely applied in green chemistry as a nano biocatalyst.

Author Contributions: Conceptualization, D.-F.T.; methodology, K.R.K., P.-Y.H., Y.-L.C., C.H.W. and W.L.; software, K.R.K. and P.-Y.H.; validation, K.R.K., P.-Y.H., Y.-L.C., C.H.W. and W.L.; formal analysis, K.R.K., P.-Y.H., Y.-L.C., C.H.W., W.L. and R.K.K.; resources, C.-H.L. and D.-F.T.; data curation, K.R.K., C.-H.L., D.-F.T., P.-Y.H., Y.-L.C., C.H.W., W.L. and R.K.K.; writing-original draft preparation, K.R.K., D.-F.T., R.K.K. and C.-H.L.; writing-review and editing, K.R.K., D.-F.T., R.K.K. and C.H.L.; visualization, K.R.K., D.-F.T., R.K.K. and C.-H.L.; supervision, D.-F.T., and C.-H.L.; project administration, D.-F.T.; funding acquisition, D.-F.T. All authors have read and agreed to the published version of the manuscript.

Funding: This work is partially supported by the Taiwan Ministry of Science and Technology (MOST 106-2113-M-259-005).

Institutional Review Board Statement: Not applicable.

Informed Consent Statement: Not applicable.

Data Availability Statement: Not applicable.

Conflicts of Interest: The authors declare no conflict of interest.

\section{References}

1. Atacan, K.; Çakıroğlu, B.; Özacar, M. Covalent immobilization of trypsin onto modified magnetite nanoparticles and its application for casein digestion. Int. J. Biol. Macromol. 2017, 97, 148-155. [CrossRef]

2. Perutka, Z.; Šebela, M. Pseudotrypsin: A Little-Known Trypsin Proteoform. Molecules 2018, 23, 2637. [CrossRef] [PubMed]

3. Vorob'Ev, M.M. Proteolysis of $\beta$-lactoglobulin by Trypsin: Simulation by Two-Step Model and Experimental Verification by Intrinsic Tryptophan Fluorescence. Symmetry 2019, 11, 153. [CrossRef]

4. Siddiqui, I.; Husain, Q. Stabilization of polydopamine modified silver nanoparticles bound trypsin: Insights on protein hydrolysis. Colloids Surf. B Biointerfaces 2019, 173, 733-741. [CrossRef] [PubMed]

5. Sasai, Y.; Kanno, H.; Doi, N.; Yamauchi, Y.; Kuzuya, M.; Kondo, S.-I. Synthesis and Characterization of Highly Stabilized Polymer-Trypsin Conjugates with Autolysis Resistance. Catalysts 2016, 7, 4. [CrossRef]

6. Aslani, E.; Abri, A.; Pazhang, M. Immobilization of trypsin onto $\mathrm{Fe}_{3} \mathrm{O}_{4} @ \mathrm{SiO}_{2}-\mathrm{NH}_{2}$ and study of its activity and stability. Colloids Surf. B Biointerfaces 2018, 170, 553-562. [CrossRef]

7. Sanchez, A.; Cruz, J.; Rueda, N.; Dos Santos, J.C.S.; Torres, R.; Ortiz, C.; Villalonga, R.; Fernandez-Lafuente, R. Inactivation of immobilized trypsin under dissimilar conditions produces trypsin molecules with different structures. RSC Adv. 2016, 6, 27329-27334. [CrossRef]

8. Stolarow, J.; Heinzelmann, M.; Yeremchuk, W.; Syldatk, C.; Hausmann, R. Immobilization of trypsin in organic and aqueous media for enzymatic peptide synthesis and hydrolysis reactions. BMC Biotechnol. 2015, 15, 77. [CrossRef]

9. Kankala, R.K.; Zhang, H.; Liu, C.; Kanubaddi, K.R.; Lee, C.; Wang, S.; Cui, W.; Santosaf, H.A.; Lin, K.; Chen, A. Metal SpeciesEncapsulated Mesoporous Silica Nanoparticles: Current Advancements and Latest Breakthroughs. Adv. Funct. Mater. 2019, 29, 1902652. [CrossRef]

10. Wahab, R.A.; Elias, N.; Abdullah, F.; Ghoshal, S.K. On the taught new tricks of enzymes immobilization: An all-inclusive overview. React. Funct. Polym. 2020, 152, 104613. [CrossRef]

11. Homaei, A.; Sariri, R.; Vianello, F.; Stevanato, R. Enzyme immobilization: An update. J. Chem. Biol. 2013, 6, 185-205. [CrossRef] [PubMed] 
12. Reis, C.; Sousa, E.; Serpa, J.; Oliveira, R.; Santos, J. Design of immobilized enzyme biocatalysts: Drawbacks and opportunities. Quím. Nova 2019, 42, 768-783. [CrossRef]

13. Liu, C.; Saeki, D.; Matsuyama, H. A novel strategy to immobilize enzymes on microporous membranes via dicarboxylic acid halides. RSC Adv. 2017, 7, 48199-48207. [CrossRef]

14. Xing, R.; Ma, Y.; Wang, Y.; Wen, Y.; Liu, Z. Specific recognition of proteins and peptides via controllable oriented surface imprinting of boronate affinity-anchored epitopes. Chem. Sci. 2019, 10, 1831-1835. [CrossRef]

15. Ansell, R.J.; Mosbach, K. Magnetic molecularly imprinted polymer beads for drug radioligand binding assay. Analyst 1998, 123, 1611-1616. [CrossRef]

16. Tan, C.J. and Y.W. Tong, Preparation of Superparamagnetic Ribonuclease A Surface-Imprinted Submicrometer Particles for Protein Recognition in Aqueous Media. Anal. Chem. 2007, 79, 299-306. [CrossRef]

17. Jing, T.; Du, H.; Dai, Q.; Xia, H.; Niu, J.; Hao, Q.; Mei, S.; Zhou, Y. Magnetic molecularly imprinted nanoparticles for recognition of lysozyme. Biosens. Bioelectron. 2010, 26, 301-306. [CrossRef]

18. Guerreiro, A.; Poma, A.; Karim, K.; Moczko, E.; Takarada, J.; De Vargas-Sansalvador, I.P.; Turner, N.; Piletska, E.; De Magalhães, C.S.; Glazova, N.; et al. Influence of Surface-Imprinted Nanoparticles on Trypsin Activity. Adv. Healthc. Mater. 2014, 3, 1426-1429. [CrossRef]

19. Tai, D.-F.; Jhang, M.-H.; Chen, G.-Y.; Wang, S.-C.; Lu, K.-H.; Lee, Y.-D.; Liu, H.-T. Epitope-Cavities Generated by Molecularly Imprinted Films Measure the Coincident Response to Anthrax Protective Antigen and Its Segments. Anal. Chem. 2010, 82, 2290-2293. [CrossRef]

20. Tai, D.-F.; Ho, Y.-F.; Wu, C.-H.; Lin, T.-C.; Lu, K.-H.; Lin, K.-S. Artificial-epitope mapping for CK-MB assay. Analyst 2011, 136, 2230-2233. [CrossRef]

21. Chou, C.-Y.; Lin, C.-Y.; Wu, C.-H.; Tai, D.-F. Sensing HIV Protease and Its Inhibitor Using "Helical Epitope"-Imprinted Polymers. Sensors 2020, 20, 3592. [CrossRef] [PubMed]

22. Collins, J.M.; Porter, K.A.; Singh, S.K.; Vanier, G.S. High-Efficiency Solid Phase Peptide Synthesis (HE-SPPS). Org. Lett. 2014, 16, 940-943. [CrossRef] [PubMed]

23. Yang, Q.; Zhu, Y.; Luo, B.; Lan, F.; Wu, Y.; Gu, Z. pH-Responsive magnetic nanospheres for the reversibly selective capture and release of glycoproteins. J. Mater. Chem. B 2017, 5, 1236-1245. [CrossRef] [PubMed]

24. Ding, S.; Xing, Y.; Radosz, M.; Shen, Y. Magnetic Nanoparticle Supported Catalyst for Atom Transfer Radical Polymerization. Macromolecules 2006, 39, 6399-6405. [CrossRef]

25. Ellwanger, A.; Karlsson, L.; Owens, P.K.; Berggren, C.; Crecenzi, C.; Ensing, K.; Bayoudh, S.; Cormack, P.A.; Sherrington, D.; Sellergren, B. Evaluation of methods aimed at complete removal of template from molecularly imprinted polymers. Analyst 2001, 126, 784-792. [CrossRef]

26. Lorenzo, R.A.; Carro, A.M.; Alvarez-Lorenzo, C.; Concheiro, A. To remove or not to remove? The challenge of extracting the template to make the cavities available in Molecularly Imprinted Polymers (MIPs). Int. J. Mol. Sci. 2011, 12, 4327-4347. [CrossRef]

27. Gerdon, A.E.; Wright, D.W.; Cliffel, D.E. Quartz Crystal Microbalance Detection of Glutathione-Protected Nanoclusters Using Antibody Recognition. Anal. Chem. 2005, 77, 304-310. [CrossRef]

28. Diltemiz, S.E.; Hür, D.; Ersöz, A.; Denizli, A.; Say, R. Designing of MIP based QCM sensor having thymine recognition sites based on biomimicking DNA approach. Biosens. Bioelectron. 2009, 25, 599-603. [CrossRef]

29. Tai, D.-F.; Lin, Y.-F.; Lu, K.-H.; Chen, G.-Y.; Shu, H.-C. A Direct Immersion System for Peptide Enrichment. J. Chin. Chem. Soc. 2012, 59, 338-344. [CrossRef]

30. Bossi, A.M.; Sharma, P.S.; Montana, L.; Zoccatelli, G.; Laub, O.; Levi, R. Fingerprint-Imprinted Polymer: Rational Selection of Peptide Epitope Templates for the Determination of Proteins by Molecularly Imprinted Polymers. Anal. Chem. 2012, 84, 4036-4041. [CrossRef]

31. Van Rosmalen, M.; Krom, M.; Merkx, M. Tuning the Flexibility of Glycine-Serine Linkers To Allow Rational Design of Multidomain Proteins. Biochemistry 2017, 56, 6565-6574. [CrossRef] [PubMed]

32. Dong, H.; Sharma, M.; Zhou, H.-X.; Cross, T.A. Glycines: Role in $\alpha$-Helical Membrane Protein Structures and a Potential Indicator of Native Conformation. Biochemistry 2012, 51, 4779-4789. [CrossRef] [PubMed]

33. Transue, T.R.; Krahn, J.M.; Gabel, S.A.; Derose, A.E.F.; London, R.E. X-ray and NMR Characterization of Covalent Complexes of Trypsin, Borate, and Alcohols. Biochemistry 2004, 43, 2829-2839. [CrossRef] [PubMed]

34. Isidro-Llobet, A.; Kenworthy, M.N.; Mukherjee, S.; Kopach, M.E.; Wegner, K.; Gallou, F.; Smith, A.G.; Roschangar, F. Sustainability Challenges in Peptide Synthesis and Purification: From R\&D to Production. J. Org. Chem. 2019, 84, 4615-4628. [CrossRef] [PubMed]

35. Wei, Y.; Thyparambil, A.A.; Latour, R.A. Protein helical structure determination using CD spectroscopy for solutions with strong background absorbance from 190 to $230 \mathrm{~nm}$. Biochim. Biophys. Acta (BBA) Proteins Proteom. 2014, 1844, 2331-2337. [CrossRef] [PubMed]

36. Farjadian, F.; Ghasemi, S.; Mohammadi-Samani, S.; Ghasemia, S. Hydroxyl-modified magnetite nanoparticles as novel carrier for delivery of methotrexate. Int. J. Pharm. 2016, 504, 110-116. [CrossRef] [PubMed]

37. Gao, Z.; Yi, Y.; Zhao, J.; Xia, Y.; Jiang, M.; Cao, F.; Zhou, H.; Wei, P.; Jia, H.; Yong, X. Co-immobilization of laccase and TEMPO onto amino-functionalized magnetic $\mathrm{Fe} 3 \mathrm{O} 4$ nanoparticles and its application in acid fuchsin decolorization. Bioresour. Bioprocess. 2018, 5, 27. [CrossRef] 
38. Kurtan, U.; Baykal, A. Fabrication and characterization of $\mathrm{Fe}_{3} \mathrm{O}_{4} @$ APTES@PAMAM-Ag highly active and recyclable magnetic nanocatalyst: Catalytic reduction of 4-nitrophenol. Mater. Res. Bull. 2014, 60, 79-87. [CrossRef]

39. Farjadian, F.; Hosseini, M.; Ghasemi, S.; Tamami, B. Phosphinite-functionalized silica and hexagonal mesoporous silica containing palladium nanoparticles in Heck coupling reaction: Synthesis, characterization, and catalytic activity. RSC Adv. 2015, 5, 79976-79987. [CrossRef]

40. Iijima, M.; Kamiya, H. Surface Modification for Improving the Stability of Nanoparticles in Liquid Media. KONA Powder Part. J. 2009, 27, 119-129. [CrossRef]

41. Boitard, C.; Lamouri, A.; Menager, C.; Griffete, N. Whole Protein Imprinting over Magnetic Nanoparticles Using Photopolymerization. ACS Appl. Polym. Mater. 2019, 1, 928-932. [CrossRef]

42. $\mathrm{Xu}$, J.; Prost, E.; Haupt, K.; Bui, B.T.S. Direct and sensitive determination of trypsin in human urine using a water-soluble signaling fluorescent molecularly imprinted polymer nanoprobe. Sens. Actuators B Chem. 2018, 258, 10-17. [CrossRef]

43. Lin, H.; Zhang, C.; Lin, Y.; Chang, Y.; Crommen, J.; Wang, Q.; Jiang, Z.; Guo, J. A strategy for screening trypsin inhibitors from traditional Chinese medicine based on a monolithic capillary immobilized enzyme reactor coupled with offline liquid chromatography and mass spectrometry. J. Sep. Sci. 2019, 42, 1980-1989. [CrossRef] [PubMed]

44. Bayramoglu, G.; Çelikbıçak, Ö.; Arica, Y.; Salih, B. Trypsin Immobilized on Magnetic Beads via Click Chemistry: Fast Proteolysis of Proteins in a Microbioreactor for MALDI-ToF-MS Peptide Analysis. Ind. Eng. Chem. Res. 2014, 53, 4554-4564. [CrossRef]

45. Zdarta, J.; Antecka, K.; Jęrzak, A.; Synoradzki, K.; Łuczak, M.; Jesionowski, T. Biopolymers conjugated with magnetite as support materials for trypsin immobilization and protein digestion. Colloids Surf. B Biointerfaces 2018, 169, 118-125. [CrossRef] [PubMed]

46. Arica, M.Y.; Şenel, S.; Alaeddinoğlu, N.G.; Patir, S.; Denizli, A. Invertase immobilized on spacer-arm attached poly(hydroxyethyl methacrylate) membrane: Preparation and properties. J. Appl. Polym. Sci. 2000, 75, 1685-1692. [CrossRef]

47. Homaei, A. Enhanced activity and stability of papain immobilized on CNBr-activated sepharose. Int. J. Biol. Macromol. 2015, 75, 373-377. [CrossRef]

48. Shojaei, F.; Homaei, A.; Taherizadeh, M.R.; Kamrani, E. Characterization of biosynthesized chitosan nanoparticles from Penaeus vannamei for the immobilization of P. vannamei protease: An eco-friendly nanobiocatalyst. Int. J. Food Prop. 2017, 20 (Suppl. 2), $1413-1423$.

49. Atacan, K.; Çakıroğlu, B.; Özacar, M. Improvement of the stability and activity of immobilized trypsin on modified $\mathrm{Fe}_{3} \mathrm{O}_{4}$ magnetic nanoparticles for hydrolysis of bovine serum albumin and its application in the bovine milk. Food Chem. 2016, 212, 460-468. [CrossRef]

50. Bayramoglu, G.; Yılmaz, M.; Şenel, A. Ülkü; Arıca, M.Y. Preparation of nanofibrous polymer grafted magnetic poly(GMA-MMA)g-MAA beads for immobilization of trypsin via adsorption. Biochem. Eng. J. 2008, 40, 262-274. [CrossRef]

51. Zhang, H.; Jiang, J.; Zhang, H.; Zhang, Y. Efficient Synthesis of Molecularly Imprinted Polymers with Enzyme Inhibition Potency by the Controlled Surface Imprinting Approach. ACS Macro Lett. 2013, 2, 566-570. [CrossRef]

52. Blat, Y. Non-Competitive Inhibition by Active Site Binders. Chem. Biol. Drug Des. 2010, 75, 535-540. [CrossRef] [PubMed]

53. Bayramoglu, G.; Özalp, V.C.; Arica, M.Y. Magnetic Polymeric Beads Functionalized with Different Mixed-Mode Ligands for Reversible Immobilization of Trypsin. Ind. Eng. Chem. Res. 2013, 53, 132-140. [CrossRef] 